\title{
Ichthayofaunal Diversity \& Anthropogenic Stress on Deepor Beel: the only Ramsar site in Assam
}

\author{
${ }^{1}$ Chandasudha Goswami, ${ }^{2}$ Manash P. Kalita \\ ${ }^{1} \mathrm{JRF}$, Abasaheb Garware College, ${ }^{2}$ Assam University, Assam
}

\begin{abstract}
North East India is the conjunction of Himalaya and In-Burma biodiversity hotspots. Deepor Beel, in Assam, has been designated a wetland of international importance under the Ramsar Convention on Wetlands, at the eighth meeting of the Conference of Contracting Parties (COP8) held recently at Valencia in Spain. Again, considering the varieties of bird species found in the Beel, Birdlife International has also declared Deepor Beel as an Important Bird Sanctuary. Deepor Beel which is the lone Ramsar site of Assam is facing danger from various angles. In this study, attempt has been made to identify the current conservation threats to biodiversity in and around the Beel periphery. Thus the study provides immense scope in conservation of the water birds and its habitat.
\end{abstract}

Keywords: Anthropogenic, Hotspots, Ramsar, Sanctuary, Conservation, Biodiversity.

\section{Introduction}

Deepor Beel, a permanent freshwater lake, is a former channel of the river Brahmaputra; situated on the Southern bank of the main river. It is also called a wetland under the Ramsar convention which has listed the lake in November 2002, as a Ramsar site for undertaking conservation measures on the basis of its biological and environmental importance. The beel provides its natural resources directly or indirectly, for livelihood of fourteen indigenous villages (1,700 families) nearby located in its precincts. Freshwater fish is a vital protein and source of income for these communities; the health of these people is stated to be directly dependent on the health of this wetland ecosystem. It is a large natural wetland having great biological and environmental importance besides being the only major storm water storage basin for Guwahati city (Deka and Goswami, 1992).

Besides being the breeding ground of around 17 globally threatened bird species, the most fascinating aspect of this wetland area is that it is a major 'staging ground' of migratory flyways. Not only this, the Deepor Beel is also the refuge for endangered species like the Asiatic elephant, the barking deer, the Chinese porcupine and the Sambar.

The site supports IUCN red-listed species such as the birds Pelecanus philippensis, Aythya baeri, Leptoptilos javanicus, Haliaeetus leucogaster, and L. dubius and the mammal Elephas maximus. Deepor beel is one of the largest congregations of aquatic birds found in Assam, particularly in winter. Deepor Beel supports 54 fish species belonging to 20 families. These include high concentration and diversity of indigenous freshwater species. Fish depend on the wetland for food, spawning and nursery.

The North Eastern India is considered as one of the global 'hot spots' of freshwater fish diversity in the world [2]. Various workers like Motwani [3]; Sen [4]; Chandra [ 5]; Sinha [6]; Bhattacharjya [7] ;Biswas [8]; Bhattacharjya [9] ; . Kar and Dey [10]; Biswas and Sugunan [11]; Sarma [12]; Saha and Bordoloi [13]; Bhuyan [14]; Baishya and Bordoloi [15]; Acharjee et al [16] and Binky\&Kar [17] studied the diversity of fishes in various inland water bodies of Assam.

\section{Materials And Methods}

Study area: Deepor Beel (Coordination: 26 $03^{\prime} 26^{\prime \prime}-26^{\circ} 09^{\prime} 26^{\prime \prime} \mathrm{N}$ and $90^{\circ} 36^{\prime} 39^{\prime \prime}-90^{\circ} 41^{\prime} 25^{\prime \prime} \mathrm{E}$ ), a permanent freshwater lake, is a former channel of the river Brahmaputra; situated on the Southern bank of the main river. Village Maj Jalukbari, Pachim Jalukbari, Dharapur and National Highway No.37 lie on the North of the beel; Dakhin Jalukbari, Tetelia and Pachim Baragoan to the East; Gorbhanga Reserve Forest, Chakardew Hill and Chilla Hill to the South-West and the Village Azara and Kahikuchi to the west. Deepor Beel has a meso-thermal climate. The temperature ranges between $10.6^{\circ} \mathrm{C}$ to $32^{\circ} \mathrm{C}$.

Sampling: Continuous monitoring and sampling is done so that rare indigenous fishes in different seasons are not missed for a period of one year from June, 2011 to July, 2012. Fishes are collected randomly to cover all possible habitat types. Common fishes were recorded at landing sites and a sample collection was made for certain species for further laboratory confirmation.

Survey Method: Specimens were either collected from landing site or on the river by using various gears (nets, hooks etc), hand pricking etc .Landing sites were monitored at intervals for the stipulated period, covering premonsoon, monsoon and post-monsoon seasons. For identification and classification of various fish species 
Talwar \& Jhingran (1991) and Jayaram (1999) were referred. These specimens were preserved in formalin. In addition, the nearby fishermen communities have been interviewed and gears and methods used for capturing fish were recorded.

Fishes of Deepor Beel:

\section{Results And Discussions}

Family: Notopteridae

1. Chitala chitala (Hamilton, 1822)

2. $\quad$ Notopterus notopterus (Pallas, 1769)

Family: Clupeidae

3. Gadusia chapra (Hamilton, 1822)

4. Hilsa ilisa

Family: Anabantidae

5. Anabas testudineus (Bloch, 1792)

Family: Cyprinidae

6. Ambiypharyngodon mola (Hamilton, 1822)

7. Aspidoporaria morar (Hamilton, 1822)

8. $\quad$ Puntius sophore (Hamilton, 1822)

9. Pethia ticto (Hamilton, 1822)

10. Puntius sarana sarana (Hamilton, 1822)

11. Pethia conchonius (Hamilton, 1822)

12. Catla catla (Hamilton, 1822)

13. Labeo rohita (Hamilton, 1822)

14. Labeo calbasu (Hamilton, 1822)

15. Labeo gonius (Hamilton, 1822)

16. Labeo nandina (Hamilton, 1822)

17. L. diagonelis

18. Cirrhinus reba (Hamilton, 1822)

19. Cirrhinus mrigala (Hamilton, 1822)

20. Ctenopharyngodon idella (Valenciennes, 1844)

21. Hypophthalmichthys molitrix (Valenciennes, 1844)

22. Cyprinus carpio (Linnaeus, 1758)

23. Rasbora daniconius (Hamilton, 1822)

24. Rasbora. bacaila

25. Barilius barila

26. Barilius bola

27. Labeo bata (Hamilton, 1822)

Family: Cobitidae

28. Botia Dario (Hamilton, 1822)

29. Botia histrionic (Blyth, 1860)

30. Lepidocephalichthys guntea (Hamilton, 1822)

Family: Bagridae

31. Aorichthys seenghala (Sykes, 1841)

32. Sperata aor (Hamilton, 1822)

33. Mystus tengara (Hamilton, 1822)

34. Mystus vittatus (Bloch, 1794)

Family: Siluridae

35. Ompok pabo (Hamilton, 1822)

36. Wallago attu (Bloch \& J. G. Schneider, 1801)

Family: Schilbeidae

37. Ailia coila (Hamilton, 1822)

38. Clupisoma garua (Hamilton, 1822)

Family: Claridae

39. Clarias magur (Hamilton, 1822)

Family: Heteropneuestidae

40. Heteropneustus fossilis (Bloch , 1794)

Family: Belonidae

41. Xenentodon cancila ( Hamilton, 1822)

Family: Amphipnoidae 
42. Monopterus cuchia

Family: Centropomidae

43. Chanda nama (Hamilton, 1822)

44. Chanda ranga

Family: Gobidae

45. Glossogobius giuris (Hamilton, 1822)

Family: Belontidae

46. Colisa fasciata (Bloch and Schneider, 1801)

Family: Channidae

47. Channa barca (Hamilton, 1822)

48. Channa marulius (Hamilton, 1822)

49. Channa punctatus (Bloch, 1792)

50. Channa striatus

Family: Mastacembelidae

51. Mastacembalus armatus armatus (Lacepède, 1800)

Family: Tetradontidae

52. Tetradon kutkutia (Hamilton, 1822)

Family: Cobitidae

53. Lepidocephalus gunted

Family: Nandidae (1 sp)

54. Nandus nandus (Hamilton, 1822)

\section{Anthropogenic Stress On The Beel}

Wetlands are source of livelihood to the people who live in the villages in their periphery and catchment areas. Fishing and transportation are the two foremost contributions of these areas to human settlements around them. They also provide fodder for domestic cattle and aquatic seeds such as giant water lily. Besides this, wetlands act as natural dams and reduce the speed of surface water during floods. They are known to prevent soil erosion too. Probably the most advantageous aspect of these water bodies when seen from the prospect of today's world crisis in terms of environmental degradation is the fact that they can remove and store greenhouse gases from the earth's atmosphere and hence slow down the onset of global warming.

But deterioration of these areas has been a constant phenomenon, although strict measures have now been taken. Proliferation of human settlements around their periphery encourages human encroachment and the killing of wild mammals and birds. Construction of roads, railways and industries ruin the natural balance of the ecosystem by enhancing pollution problems.

The intensive fishing activities, prevalent both by day and night, causes a considerable disturbance and also there is heavy hunting pressure on water birds. Large numbers of water birds are netted illegally during the winter months (December to March) for sale in local markets. Pesticides and fertilizers are widely used on adjacent agricultural land, and enter the lake in runoff. The fertilizers have accelerated eutrophication, and infestation with Echhornia crassipes is now becoming a serious problem.

The Deepor Beel area is being facing the problem of wastewater accumulation in its catchment area that flows from adjoining towns and cities. This causes water pollution and proves detrimental to the life nurtured by the wetland. The forests in the catchment area to the south are often being felled illegally to supply timber for the sawmills, resulting in increased erosion, which in turns, is causing rapid siltation in the beel. Settlements and permanent agriculture are steadily encroaching on the wetland and reducing the extent of the marsh vegetation. The beel is surrounded by the National Highway No. 37 on the east and north-east. Again, Construction of railway line along the southern boundary of the Deepor beel; The newly established Mother Teresa Hospital is also situated in the north western border of the Deepor beel. A number of temporary farm houses have been constructed in recent years all around the Deepor beel. Besides, several industrial units including the Border Security Forces housing complex and the Artfed industrial complex have come up in the swampy area of the beel. A number of brick kilns also operate within the beel area itself; Large scale encroachment and government as well as private settlement within the Deepor beel area; Allotting the government vacant land to private party by Government settlement department; Hunting, trapping and killing of wild birds and mammals within and in the adjoining areas of Deepor beel; Unplanned fishing and community fishing practice without controlling mesh size and using water pump, etc. are the major threats for the site.

\section{Conservation Status}

Keeping in mind all these stress, though various policies are made; deepor beel is declared as Ramsar site, Bird sanctuary etc etc ; but practically all are in void. It is unable to change the conservation status. 
Awareness among the people in right direction may save this only Ramsar site of Assam harboring immense diversity.

\section{Discussion}

According to RIS (Information Sheet on Ramsar Wetlands) report,updated on August, 2002, 50 fish species are found in Deepor Beel. Now the value is replaced by 54 species. Saikia (2005) had also reported 232 species of aquatic avian fauna belonging to 42 different families in his study in Deepor Beel. Among these species 137 species were residential and 97 species were migratory. Again, Das and Saikia(2011) explored 38 species of birds from 18 different families. Of all these species 9 species are winter visitors to the wetland and the rest 29 species are breeding residents. All the biodiversity is suffering due to anthropogenic stress. Stress level is increasing day by day crossing threshold limit. Pollution and eutrophication becomes the major threat in addition to the railway and National Highway in the surrounding. What matters more at this hour are the well plan conservative measures to be undertaken to stem the rot-the alarming decline of fish diversity.

[1] Goswami, M.M., Deka, T.K., Singh, P.K., Sarma, P.K. and Kakati, M. (1999).Studies of some wetlands of Assam with reference to the eutrophication stresses. J.Inland Fish.Soc.India 31(2):39-43.

[2] Kottelat, M. and Whitten, T. (1996). Freshwater Biodiversity in Asia with special reference to Fish .World Bank,Washington, D C, pp.17-22.

[3] Motwani, M.P., Jayaram, K.C. and Sehgal, K.L. (1962). Fish and fisheries of the Brahmaputra river system, Assam. I. Fish fauna with observations on their zoogeographical distribution. Trop. Ecol., 3: 17 -43.

[4] Sen,T.K.(1985) The Fish fauna of Assam and the neigbouring states of India. Records of the Zoological survey of India, Occasional Paper. No 64. pp. 216.

[5] Chandra, R., Yadava, Y.S., Kolekar, V. and Choudhury, M. (1999).A checklist of fishes from Dighali beel, district Kamrup, Assam. J.Inland .Fish.Soc.India., 22 (1 \&2):92- 95.

[6] Sinha, M. (1994). Fish genetic resources of the Northeastern of India. J.Inland Fish. Soc. India., 26(1): 1-9.

[7] Bhattachrjya, B.K. (2002): Trophic structure and fishery potential of selected floodplain wetlands (Beels) of Brahmaputra valley. Unpublished Ph.D Thesis, Central Institute of Fisheries Education, Mumbai. pp. 226.

[8] Biswas, S.P., Baruah, A. and Baruah, S. (2001). Conservational status of fish resources in the Brahmaputra basin. Trop. Zool., Vol.2 \& 3:125 -131.

[9] Bhattacharjya, B.K., Choudhury, M. and Sugunan, V.V. (2003). Icthyofaunistic Resources of Assam with a note on their sustainable utilization. In: Participatory approach for fish biodiversity conservation in Northeast India . Published by Director, NBFGR, Lucknow, India. pp. 87 -105.

[10] Kar, D., Nagarathna, A.V., Ramachandra, T.V. and Dey, S.C. (2006). Fish diversity and conservation aspects in an ecosystem in Northeastern India. Zoos' print journal., 21(7):2308-2315.

[11] Biswas, B.K. and Sugunan,V.V. (2008). Fish diversity of Brahmaputra river system in Assam, India. J.Inland Fish. Soc. India., 40(1): 23-31.

[12] Sarma, D., Dutta, A. and Choudhury, M. (2007).Limnology and Fisheries of Urpod beel, Goalpara, Assam. J.Inland Fish. Soc. India., 39(1):51 - 54

[13] Saha, S. and Bordoloi, S. (2009).Ichthyofaunal diversity of two beels of Goal Para district, Assam, India J.Threatened. Taxa 1(4):240-242.

[14] Bhuyan, K.C., Dutta, A. and Kalita, B.(2009). Hydrobiology and fishery of Sondoba beel, Morigaon, Assam. J.Inland Fish. Soc. India., $41(2): 48-53$

[15] Baishya, A. and Bordoloi, S. (2009). Ichthyofaunal Diversity, Socio-economic status of fisher community, Gears used and techniques of Fish Catch in Beels of Hajo, Kamrup District,Assam. Int. J. Eco. Environ. Sci., 35(1): 77 - 90.

[16] Acharjee,B., Dutta,A.,Sharma,D.K.,Dash,P.,and Behra,B.K.(2009). Ecological status of Deepor beel, Assam with special reference to its fish and fisheries. (Ed- Kosygin, L.)Wetlands of North East India: Ecology, Aquatic Bioresources and Conservation, Akansha Publishing House,NewDelhi,p, 41-54.

[17] Binky, Kh. and Kar, D. (2011).Icthyospecies diversity of Karbhala wetland in Cachar district ofAssam. Environ\&Ecol. 29(1):1719.

[18] Government of Assam, 1990. Report of the Committee on Environmental Implications associated with the B.G. Railway Alignment through the Deepor Beel Area, Government of Assam, Dispur, Guwahati 781 006, P.1-116

[19] MapSource: NATIONAL WETLAND ATLAS: ASSAM. P. 47-48

[20] Das Jyotismita and Saikia PK, September 2011; Conservation threats to the water birds in Deepor Beel, Assam. 
Ichthayofaunal Diversity \& Anthropogenic Stress on Deepor Beel: The only Ramsar site in Assam

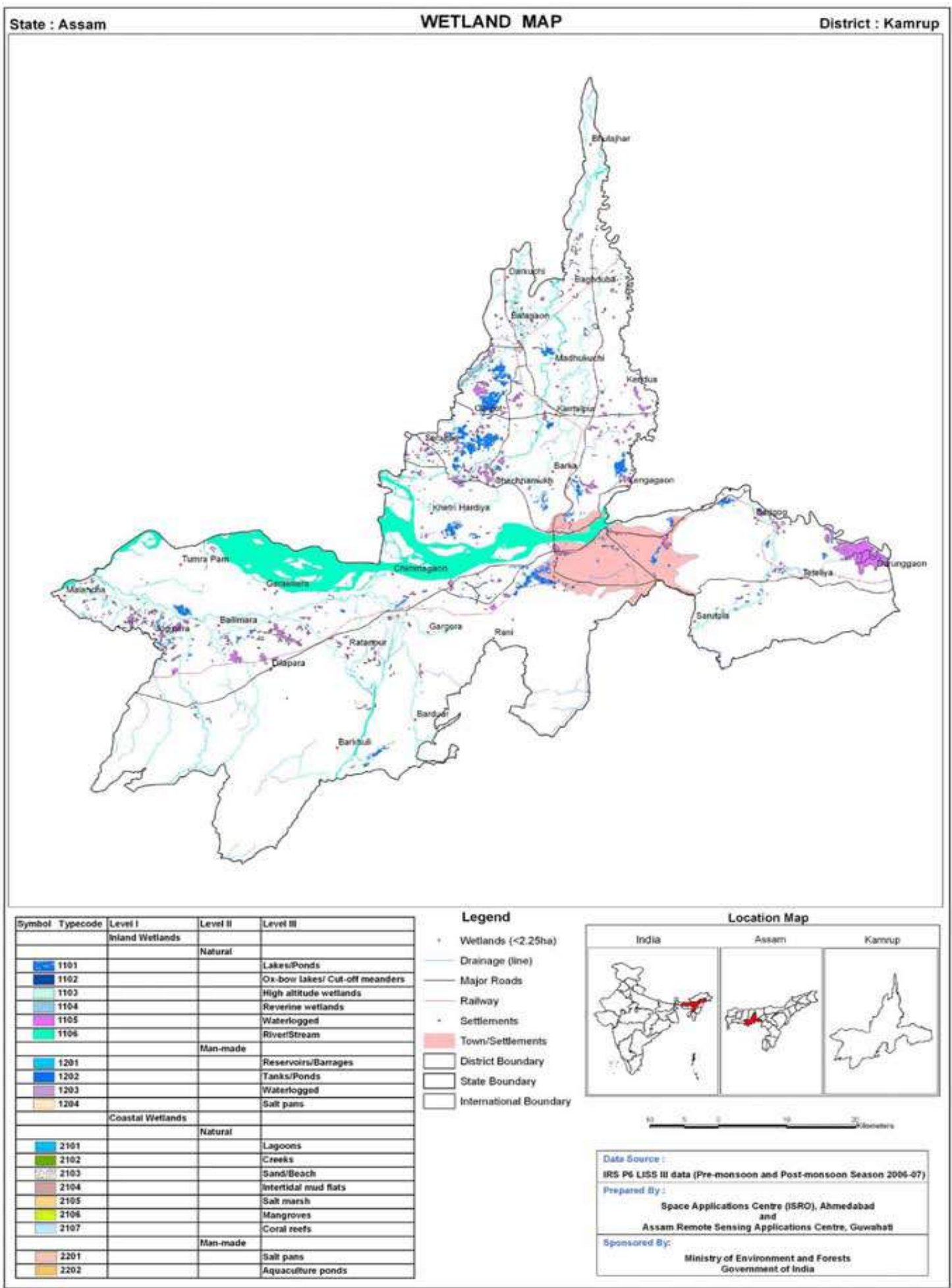


Ichthayofaunal Diversity \& Anthropogenic Stress on Deepor Beel: The only Ramsar site in Assam

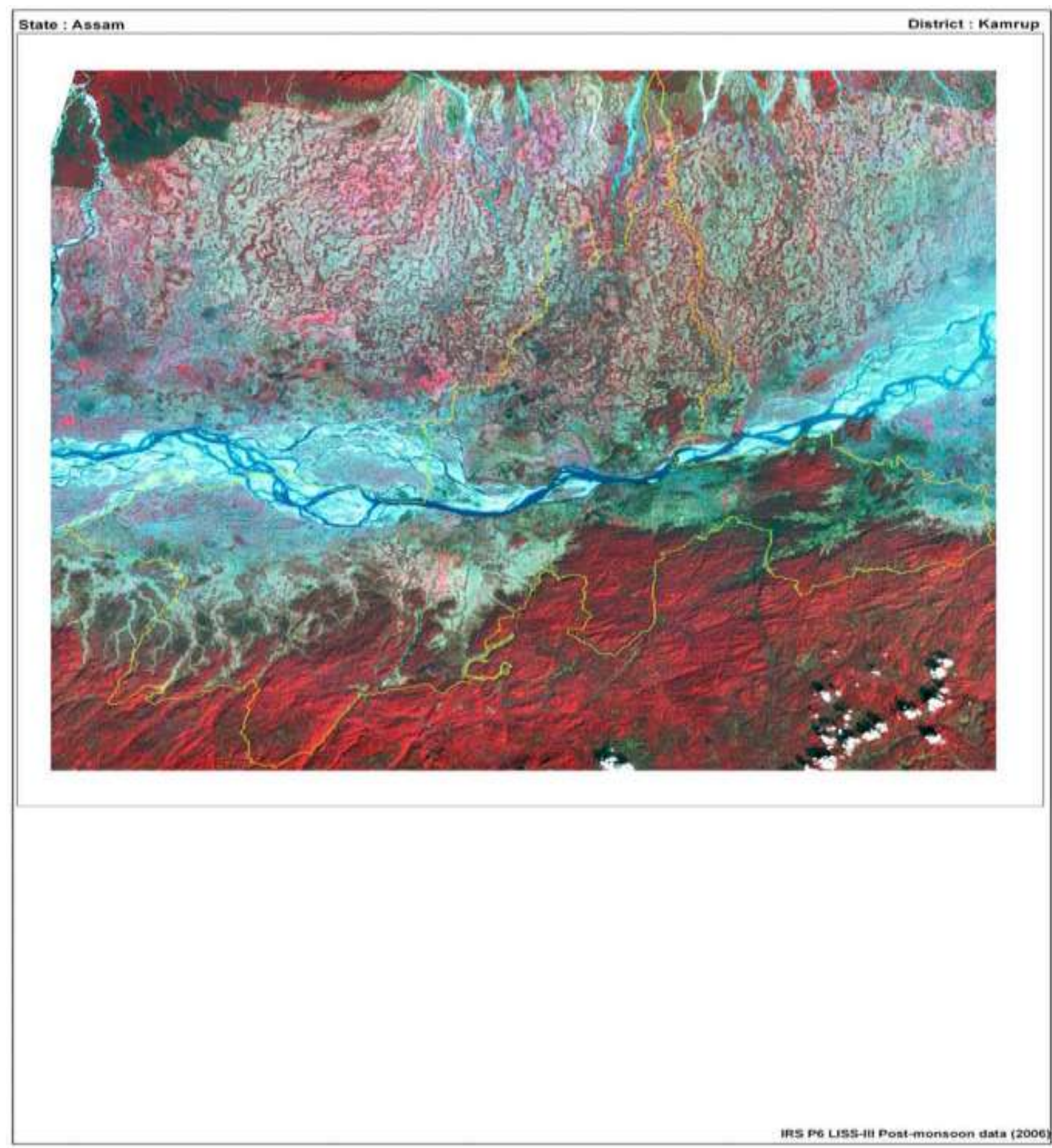

